Environment, Biodiversity \& Soil Security
(EBSS)
http://jenvbs.journals.ekb.eg//

\title{
Management of Heat Stress in Tomato Seedlings under Arid and Semi-Arid Regions: A Review
}

\author{
Neama Abdalla ${ }^{1}$, NaglaaTaha ${ }^{2}$, Hassan El-Ramady ${ }^{3}$ and Yousry Bayoumi ${ }^{4,5^{*}}$ \\ IPlant Biotechnology Dept., Genetic Engineering Division, National Research Center, \\ 33-El-Behouth Street, Giza, Egypt \\ ${ }^{2}$ Plant Pathology Research Institute, Agriculture Research Center, Sakha, Kafr El- \\ Sheikh, Egypt \\ ${ }^{3}$ Soil and Water Dept., Faculty of Agriculture, Kafrelsheikh University, Egypt \\ ${ }^{4}$ Horticulture Dept., Faculty of Agriculture, Kafrelsheikh University, Egypt \\ ${ }^{5}$ Physiology \& Breeding of Horticultural Crops Laboratory, Horticulture Dept., Faculty \\ of Agriculture, Kafrelsheikh University, Egypt.
}

\begin{abstract}
$\mathbf{T}$
HE production of protected cultivation of vegetables could be considered as a sustainable solution in arid and semi-arid regions. These regions already suffer from raising temperature andthe global warmingwill aggravate this, whichrepresents a great challenge facing our universe nowadays. Hence, the production of vegetables and tomato under greenhouse system during the high temperatures may be considered a serious problem should be avoided in these arid zonesin summer due to heat stress. The heat stress may cause a lot of troubles for the tomato seedlings in greenhouses in summer starting with the photosynthetic rate, and the metabolism processes in seedlings and in turn the growth and development of these seedlings. Although studies have recognized heat stress on tomato seedlings, research has yet to systematically investigate the effect of heat stress on tomato seedlings in greenhouse in summer under arid and semi-arid regions particularly in developing countries, which their greenhouses have not any climate controllers. Therefore, the management of tomato seedlings may need to address the production problems caused by heat stress in greenhouse conditions particularly in arid and semi-arid zones
\end{abstract}

Keywords : High temperature stress, Abiotic stress, Protected agriculture, Greenhouse.

\section{Introduction}

Climate change and global warming are serious problems threatening the agricultural production. The global temperature is projected to increase with a rate may reach 1.5 and $3.5^{\circ} \mathrm{C}$ by 2050 and 2100, respectively (Zhou et al., 2020). The high temperature or heat stress is considered one of the most devastating abiotic stresses, which becomes more serious due to the global warming (Bilal et al. 2020). High temperature stress may disturb cellular homeostasis, affects physiological and biochemical reactions, as a consequence, impedes plant growth, development and eventually reduces crop productivity (Fahad et al., 2017).
Due to many environmental problems, the protected cultivation has established to overcome these problems. It could be defined the protected agriculture or cultivation as a group of agricultural practices, which allows to produce the cultivated crop in plastic- or glass-house to protect plants fromclimatic conditions and pests (Nordey et al. 2017 and Ghani et al., 2019). This protected cultivation could be considered as a "sustainable solution" in producing the foods particularly in hot-arid environments (Ghani et al., 2019).

Tomato (Solanum lycopersicum L.) is considered a popular vegetable belongs to the family Solanaceae. This crop couldwidely grow and consume across

\footnotetext{
*Corresponding author: E-mail: ybayoumi2002@yahoo.com.sg

'E-mail: neama_ncr@yahoo.com, ${ }^{2}$ E-mail: naglaa_abdelbaset@yahoo.com

${ }^{3}$ E-mail:hassan.elramady@agr.kfs.edu.eg, ${ }^{4}$ E-mail: ybayoumi2002@yahoo.com.sg

Received 17/04/2020; Accepted 4/06/2020 
the world. Due to its high nutritional value, tomato is considered the second favored and consumed vegetable crop after potato in the world (Siddiqui et al., 2020). Tomato fruits have the abundant nutrients (e.g., copper, selenium, manganese and zinc), antioxidants (lycopene and $\beta$-carotene), active components (e.g., poly-phenols and carotenoids), nutritional organic acids (ascorbic, citric and malic acid)and vitaminslike C, E and A (Singh et al., 2018). The tomato fruit is called "the poor man's orange" because these fruits are rich in vitamin $\mathrm{C}$, malic and citric acids as well as its low price (Alsuhaibani, 2018).The global production of tomato was estimated to be approximately 182 million tons in 2017 (FAOSTAT, 2019). The cultivation and production of tomato may decrease due to the stress of unfavorable climatic conditions or climate changes and the imbalance supply of nutrients(Naz et al., 2019 and Siddiqui et al., 2020). This stress may affect different biochemical and physiological parameters of tomato plants. Under the arid and semi-arid conditions, tomato may face multiple stresses including drought and heat stress. Concerning the impact of high temperature on tomato, it is reported that the tomato growth may be impeded during the summer period threatening the yield (Zhou et al., 2020).

The global production of tomato, like other cultivated crops, face many challenges particularly the biotic (i.e., plant pathogens including bacteria, fungi, nematodes and viruses) and abiotic stresses (e.g., salinity, drought, waterlogging, chilling and heat stress).Different physiological, biochemical, morphological and molecular changes represent the response of cultivated plants to the environmental challenges, which adversely lead to decrease the plant growth and its productivity (Zandalinas et al., 2018). Thus, these previous stresses cause direct and indirect reduction in the growth and yield of tomato (Singh et al., 2018). Under changing climate and global warming, the heat stress could be considered one of the most important stresses limiting tomato productivity beside drought and salinity particularly in arid and semi-arid zones. It is worth mentioning that, the abiotic stress in agroecosystems could be mediated by nanomaterial (Elsakhawy et al., 2018), seeking for the sustainable irrigation and fertilization (Amer et al., 2019) and plant nutrition (El-Ramady et al., 2020).

Therefore, this review aimed to address the heat stress as a global issue and its impact on tomato seedlings production. The protected tomato seedlings under heat stress in the greenhouse in arid and semi-arid zones and its management also will be discussed.

\section{Tomato as a Model Plant}

Tomato (Solanum lycopersicum L.) is considered a popular vegetable worldwide. This Solanaceous seedling has categorized as an important model plant in investigating the stress tolerance (Zhang et al., 2018). So, several stress studies have been carried on tomato seedlings such as heat stress (Lyu et al., 2018), water stress (Zhang et al. 2018), drought (Bian et al., 2019), salinity (Zhou et al. 2019), UV-B stress (Liu et al., 2020), chilling (Dong et al., 2020), and waterlogging (Elkelish et al., 2020). Many strategies could be adapted to overcome these stresses depending on the kind of stress, cultivated plants and its growth stage (Zhou et al., 2020). Several researchers reported about these strategies for tomato seedlings, which include the application of spermidine (Sang et al., 2016), Ca, Mg and $\mathrm{K}$ compounds (Sakhonwasee and Phingkasan, 2017 and Nafees et al., 2019), ascorbic acid (Alayafi, 2019), melatonin and salicylic acid (Jahanet al., 2019, 2020b) as well as proline (Tonhati et al., 2020). Therefore, the production of tomato seedlings under greenhouse conditions may face some stresses, which still need more and more investigations in particular in arid and semi-arid regions in summer (Fig. 1). To what extend how the greenhouse could guarantee the highest yield of tomato for a long time under heat stress in arid zones? To what extend how heat stress could increase soil salinization and its degradation during tomato seedlings production in arid zones? To what extend how the greenhouse could support the tomato seedlings production in summer in arid zones?

\section{Protected Cultivation of Tomato Seedlings and Stress}

It could be defined the "protected agriculture" as a cropping technique, by which the microenvironment surrounding the cultivated plants could be controlled partially or fully modify during their period of growth to maximize the productivity(Nordey et al. 2017). The protected cultivation has a great potential in increasing the productivity of vegetables (e.g., pepper, tomato, strawberry, cucumber and green beans) and flower crops (e.g., rose, gerbera, orchid, chrysanthemum and carnation) by several folds (Reddy 2016). This protected agriculture has several advantages particularly in arid and semi-arid zones such as (1) a high yield in greenhouse comparing with open field, (2) a high protection from dis- 
eases and pests as well as undesirable climatic conditions, (3) the possibility to cultivate crops during off-season compared with the open fields, and (4) the excellent opportunity to produce in high quality crops for exportation in greenhouses (Reddy, 2016). The use of greenhouse in arid and semi-arid zones has been the subject of intense debate within the scientific community due to itsmany environmental problems and economic benefits as well. The environmental problemsmay result from the long-term production of vegetable, intensiveuse of fertilizers and irrigation under greenhouse conditions in arid and semi-arid leading to soil pollution and degradation and gas emissions as well (Liang et al., 2013; Sun et al., 2018 and Shurpali et al., 2019).

Due to the rapid growth in populations, the dramatic fluctuations in atmospheric temperature and the limited sources of arable lands, the greenhouses are considered intensive tools of agriculture, which have been widely applied worldwide (Sun et al., 2018). Under greenhouse conditions, daily fluctuations in both temperature and light could control the growth of plants creating biotic and abiotic stresses. The fluctuations in essential mineral nutrients bioavailability could be mainly influenced by the soil physico-chemical properties and their biological activities (Bouain et al., 2019). Therefore, the production of tomato seedlings in the greenhouse could be maximized in winter but in summer may face a heat stress in arid and semi-arid.

The production of tomato seedlings in thegreenhouse mainly is controlled by many factors like the right applied source, rate, time and place of nutrients. Nutrients are considered the key factorinthe growth of plants and development, which their bioavailability in the rhizosphere mainly regulate the plant biomass and productivity (Pandey et al., 2020). The overdose of these nutrients may be represented as a real threat causing nutrient stress in production of tomato seedlings (Table 1). The response of tomato seedlings towards the nutrient stress may depend on the growth conditions, anti-stress used and its recommended dose (Table 1). There are several anti-stress could be applied to mitigate the abiotic stress on cultivated plants (e.g., nitric oxide, abscisic acid, melatonin, gibberellins and kinetin). The role of anti-stress in mitigation of the nutrient stress of tomato seedlings could be handled in the following sub-sections.

Nitric oxide (NO) is"redox-related signaling molecule" and a "gaseous free radical", which could regulate the growth of plants and its development (Gupta et al., 2019). This molecule also could support cultivated plants against abiotic stress because NO can regulate a lot of proteins activity and related-genes expression under stress (Siddiqui et al., 2020 and Wei et al., 2020). It is reported that, NO could participate in the plant mechanism towards abiotic stress like heat stress and other abiotic stresses. This NO can abate the deleterious effects of different stresses through the biosynthesis activation of thiol (R-SH) compounds like glutathione and phytochelatin (Siddiqui et al., 2020). It is reported by many researchers that nitric oxide could ameliorate the harmful effects of many stresses on tomato seedlings such as salt stress through increasing theseenzymatic antioxidants (peroxidase, catalase, glutathione reductase, superoxide dismutase and ascorbate peroxidase) and photosynthetic pigment as well as decreasing the content of malondialdehyde and reactive oxygen species (Siddiqui et al., 2017). Under cadmium stress, applied NO could promote the tomato growth by modulating the metabolism of osmolytes, ascorbate-glutathione cycle enzymes and antioxidants (Ahmad et al., 2018). The ameliorative role of nitric oxide has been reported also under nutrient stress like copper stress (Dong et al., 2013 and Wang et al., 2015), sulfur stress (Siddiqui et al., 2020), boron (Kaya and Ashraf, 2015) and heavy metals (Wei et al., 2020).

Melatonin (N-acetyl-5-methoxytryptamine) is considered a plant hormone, which was isolated from the pineal gland of bovines in 1958 and plants in 1995 (Agathokleous et al., 2019). Several researchers have been reported aboutmelatonin as a "pleiotropic signaling molecule", which could be produced in plants and animals as a hormone under stress (e.g., Mukherjee, 2018; Arnao and Hernández-Ruiz, 2019 and Jahan et al., 2020a). This plant hormone called "plant master regulator" due to its multiple biological roles as well as defensive roles under changing environmental conditions (Arnao and Hernández-Ruiz, 2019). These stressful conditions on plants include drought (Dai et al., 2020), salinity (Zahedi et al., 2020), heavy metals like chromium (Seleiman et al., 2020), heat stress (Jahan et al., 2020a) and oxidative stress (Jahan et al., 2020b). Under heat stress, melatonin could increase the tolerance of tomato seedlings towards heat stress through inducing the cycle of ascorbateglutathione,improving the defense mechanism of their antioxidants and re-program the metabolic of polyamine and nitric oxide biosynthesis pathways (Jahan et al., 2020a). Melatonin also could mitigate the oxidative stress, which may be induced by heat stress of tomato seedlings through scavenging of excess reactive oxygen species and increasing the stability of the cellular membranes (Jahan et al., 2020a). 

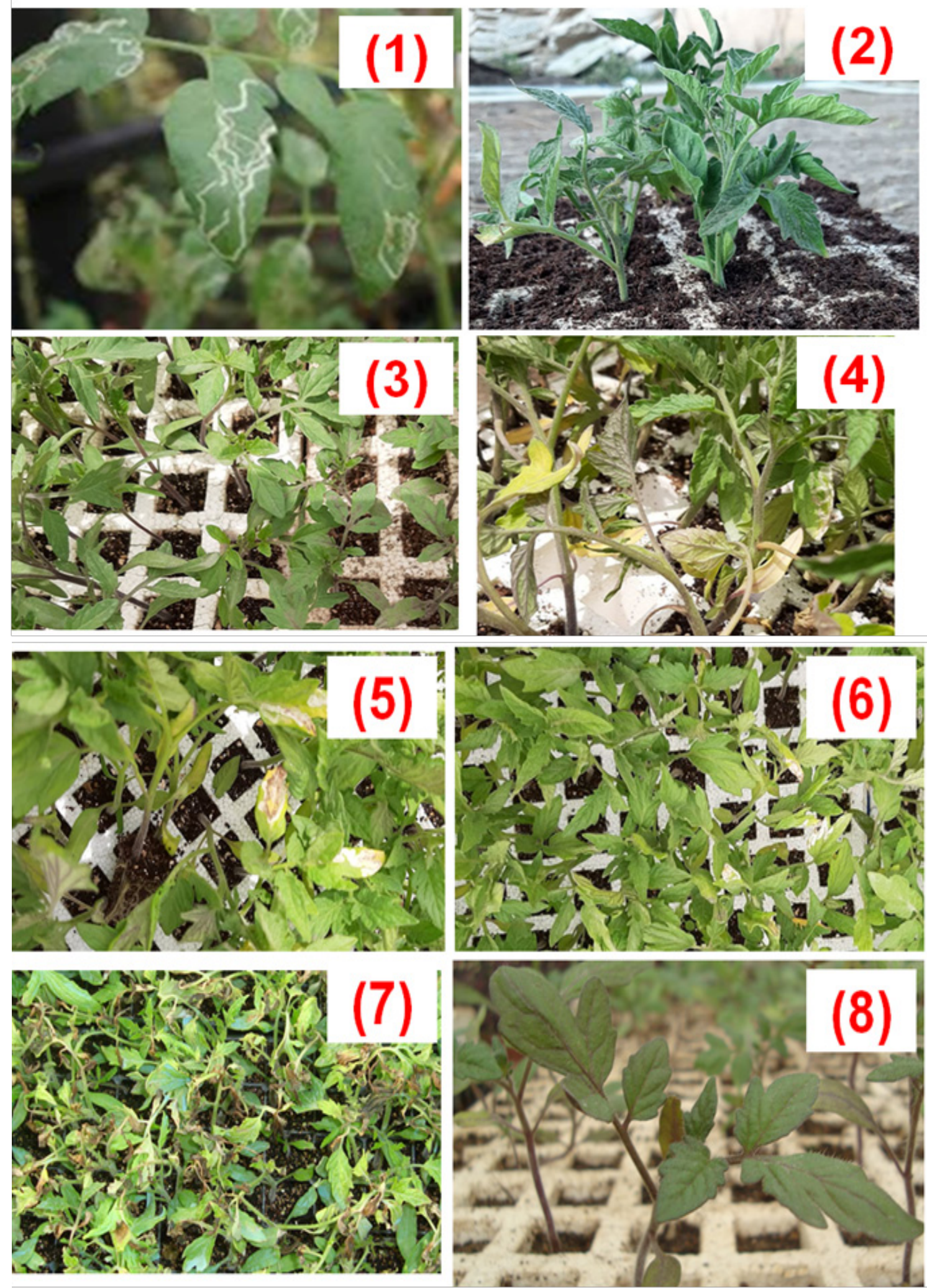

Fig. 1. There are many distinguished stresses have been reported for tomato seedlings grown under greenhouse in arid and semi-arid zones like in Egypt: leaf miners (photo 1), irrigation with saline water (photo 2), low temperature stress (photo 3), late blight (photo 4), Tutaabsoluta (photo 5), N-deficiency (photo 6), early blight (photo 7) and P-deficiency stress (photo 8) (All photos by authors) 
TABLE 1. Response of tomato seedlings to nutrient stress, the growth conditions, anti-stress used and its recommended dose.

\begin{tabular}{|c|c|c|c|c|c|}
\hline $\begin{array}{c}\text { Cultivar (cv.) or } \\
\text { variety name }\end{array}$ & $\begin{array}{c}\text { Growth } \\
\text { conditions }\end{array}$ & Nutrient stress & Anti-stress & $\begin{array}{c}\text { Used dose of } \\
\text { anti-stress }\end{array}$ & Reference \\
\hline cv: Five Star & $\begin{array}{l}\text { Sand and perlite } \\
\text { (1:1 ratio) } \\
\text { pots, growth } \\
\text { chamber }\end{array}$ & $\begin{array}{l}\text { Sulfur deficiency } \\
\left(\mathrm{SO}_{4}: 71 \mathrm{mg} \mathrm{l}^{-1}\right)\end{array}$ & $\begin{array}{l}\text { Nitric oxide } \\
\quad(\mathrm{NO})\end{array}$ & $\begin{array}{c}\text { NO at } 100 \mu \mathrm{M} \\
\text { SNP }\end{array}$ & $\begin{array}{l}\text { Siddiqui et al. } \\
\quad(2020)\end{array}$ \\
\hline ----- & $\begin{array}{l}\text { Hydroponic } \\
\text { culture, }\end{array}$ & $\begin{array}{l}\text { Palladium stress } \\
(0.2,0.5,1.0 \mathrm{mM} \\
\left.\text { of } \mathrm{PdCl}_{2}\right)\end{array}$ & Palladium (Pd) & $\begin{array}{c}\mathrm{Pd} \text { at } 0.2 \mathrm{mM} \\
\mathrm{PdCl}_{2}\end{array}$ & $\begin{array}{l}\text { Zhao et al. } \\
\text { (2020) }\end{array}$ \\
\hline cv: Ailsa Craig & Growth chamber & $\begin{array}{c}\mathrm{NH}_{4}^{+} \text {toxicity }(10 \\
\mathrm{mM})\end{array}$ & $\begin{array}{l}\text { Abscisic acid } \\
\text { (ABA) }\end{array}$ & $\mathrm{ABA}$ at $0.1 \mu \mathrm{M}$ & $\begin{array}{l}\text { González- } \\
\text { Hernández et } \\
\text { al. (2020) }\end{array}$ \\
\hline $\begin{array}{l}\text { Variety:Zhongshu } \\
4\end{array}$ & $\begin{array}{l}\text { Greenhouse, pots } \\
\text { filled with soil } \\
\text { (pH: } 7.91)\end{array}$ & $\begin{array}{l}\text { Toxicity of } \mathrm{Cu} \& \\
\mathrm{Cd}(500 \text { and } 8 \mathrm{mg} \\
\left.\mathrm{kg}^{-1}, \text { resp. }\right)\end{array}$ & $\begin{array}{l}\text { Poly-aspartic } \\
\text { acid (PASP) }\end{array}$ & $\begin{array}{l}\text { PASP at } 700 \\
\quad \mathrm{mg} \mathrm{l}^{-1}\end{array}$ & Hu et al. (2019) \\
\hline cv. Five Star & $\begin{array}{l}\text { Sand and perlite } \\
(2: 1 \text { ratio) } \\
\text { pots, growth } \\
\text { chamber }\end{array}$ & $\begin{array}{l}\text { Toxicity of } \\
\text { lanthanum }(1.5 \\
\text { mM La) }\end{array}$ & $\begin{array}{l}\text { Melatonin } \\
\text { (Mel) and } \\
\text { sulfur (S) }\end{array}$ & $\begin{array}{l}\operatorname{Mel}(150 \mu \mathrm{M}), \mathrm{S} \\
\left(1.0 \mathrm{mM} \mathrm{SO}_{4}{ }^{2-}\right)\end{array}$ & $\begin{array}{l}\text { Siddiqui et al. } \\
\text { (2019) }\end{array}$ \\
\hline ----- & Peat moss in trays & $\begin{array}{l}\text { Toxicity of Se \&Ce } \\
(20 \text { and } 100 \mu \mathrm{M})\end{array}$ & $\begin{array}{l}\text { Selenium }(\mathrm{Se}) \\
\text { and cerium } \\
(\mathrm{Ce})\end{array}$ & $\begin{array}{l}5 \text { and } 50 \mu \mathrm{M} \\
\text { for Se and Ce, } \\
\text { respectively }\end{array}$ & $\begin{array}{c}\text { Saldaña- } \\
\text { Sánchez et al. } \\
\text { (2019) }\end{array}$ \\
\hline ---- & $\begin{array}{l}\text { Pots filled with } \\
\text { hydroponic } \\
\text { solution }\end{array}$ & $\begin{array}{c}\text { Toxic selenite } \& \\
\text { selenate }(>0.1 \&> \\
\left.1 \mathrm{mg} \mathrm{Se} 1^{-1}\right)\end{array}$ & $\begin{array}{l}\text { Se in selenite } \\
\& \text { selenate }\end{array}$ & $\begin{array}{l}0.05 \mathrm{mg} \mathrm{l}^{-1} \text { for } \\
\text { both selenite \& } \\
\text { selenate }\end{array}$ & $\begin{array}{l}\text { Wang et al. } \\
\text { (2019) }\end{array}$ \\
\hline $\begin{array}{l}\text { cv. M82 and cv. } \\
\text { MicroTom }\end{array}$ & 1/2 MS medium & $\begin{array}{c}\text { Phosphate } \\
\text { starvation }(10 \mu \mathrm{M} \\
\text { Pi) }\end{array}$ & $\begin{array}{l}\text { Gibberellins } \\
\quad\left(\mathrm{GA}_{3}\right)\end{array}$ & $10 \mu \mathrm{M} \mathrm{GA}_{3}$ & $\begin{array}{l}\text { Zhang et al. } \\
\text { (2019) }\end{array}$ \\
\hline -------------- & $\begin{array}{l}\text { Pots filled with } \\
\text { sand, perlite and } \\
\text { peat }(1: 1: 1)\end{array}$ & $\begin{array}{c}\text { Cadmium toxicity: } \\
\qquad 150 \mu \mathrm{M}\end{array}$ & $\begin{array}{l}\text { Nitric oxide } \\
\quad(\mathrm{NO})\end{array}$ & NO $(100 \mu \mathrm{M})$ & $\begin{array}{l}\text { Ahmad et al. } \\
\qquad(2018)\end{array}$ \\
\hline cv. K-21 & $\begin{array}{l}\text { Pots filled with } \\
\text { sand and perlite } \\
\quad(1: 3 \text { ratio })\end{array}$ & $\begin{array}{l}\text { Cadmium }(\mathrm{Cd}) \\
\text { toxicity: } 150 \mathrm{mg} \mathrm{l}^{-1}\end{array}$ & $\begin{array}{l}\text { Selenium as } \\
\text { selenite }\end{array}$ & $\begin{array}{c}\mathrm{Se}(10 \mu \mathrm{M} \\
\left.\mathrm{Na}_{2} \mathrm{SeO}_{3} \cdot{ }^{\circ} \mathrm{H}_{2} \mathrm{O}\right)\end{array}$ & $\begin{array}{c}\text { Alyemeni et al. } \\
\text { (2018) }\end{array}$ \\
\hline cv. Lakshmi & Growth chamber & $\begin{array}{l}\text { Cadmium toxicity } \\
\left(9 \mathrm{mg} \mathrm{Cd} \mathrm{kg}^{-1}\right)\end{array}$ & Kinetin $(\mathrm{KN})$ & $\mathrm{KN}: 10 \mu \mathrm{M}$ & $\begin{array}{l}\text { Singh et al. } \\
\quad(2018)\end{array}$ \\
\hline
\end{tabular}

Note: SNP $\left(\mathrm{Na}_{2}\left[\mathrm{Fe}(\mathrm{CN})_{5} \mathrm{NO}\right] ._{2} \mathrm{H}_{2} \mathrm{O}\right.$, which was used as an $\mathrm{NO}$ donor)

Brassinosteroids (BRs) are a plant hormone, which support cultivated plants in the growth, development and stress tolerance (Tong and Chu, 2018 and Pandey et al., 2020). Brassinosteroid is "poly-hydroxylated steroid phyto-hormone" having unique key roles during the early development of seedlings, flowering stage, vascular development and development of roots (Lee et al. 2018; Ahanger et al. 2020; Setsungnern et al. 2020). The tolerance of plants towards stress may depend on the interaction between BRs and other phytohormones including auxin, cytokinins, salicylic acid, and ethylene (Ahanger et al., 2020). It is reported about the promising role of
appliedBRs in protecting the environment under stress (Soares et al., 2020). Exogenous applied and endogenous BRs was found to increase the tolerance of tomato plants against different stresses such as salinity (Ahanger et al. 2020), drought (Jangid and Dwivedi, 2017, Lee et al., 2018 and Nie et al., 2019), low temperature stress (Khan et al., 2019) and for other stressed plants like heat stress on Arabidopsis (Setsungnern et al., 2020), cadmium stress on pepper (Kaya et al., 2020), lead stress on Brassica juncea (Soares et al., 2020) and heat stress on barley (Sadura et al., 2020).Therefore, BRs are plant growth regulators that recognize the promoting the 
division and stretching of plant cells, vascular differentiationandthe resistance against stressful conditions (Soares et al., 2020).

\section{Management and Production of Protected Tomato Seedlings under Heat Stress}

The universe faces a lot of troubles including the population explosion, climate changes and global warming as well as the overexploitation of natural resources, which threaten the loss of global biodiversity (Souza and Prevedello, 2020). The changing in climate could threaten the crop production throughthe physical damage resulting from extreme climate events such as flooding and drought as well asthe physiological changes induced by heat stress(Wan, 2015). Temperature is considered the most important environmental factor affecting the crop production, where each plant growth stage is totally controlled by temperature (Sakhonwasee and Phingkasan, 2017). Due to the extreme high temperatures particularly under arid zones, the cultivated plants in greenhouse will suffer from the heat stress in summer. The heat stress may support the over-production of reactive oxygen species (ROS), which damage the plant defense system and reduce its growth rates (Jahan et al., 2019).

The production of tomato seedlings under heat stress has gained the attention of many researchers as presented in Table 2. They found that tomato seedlings can mitigate the harmful effects of the heat stress by exogenous applied many anti-stress like applied calcium compounds (Sakhonwasee and Phingkasan, 2017), spermidine (Sang et al., 2016), ascorbic acid (Alayafi, 2019), nitrate compounds (Nafees et al. 2019), salicylic acid (Jahan et al., 2019), melatonin (Jahan et al., 2020b), sucrose andsilicon (EL-Aidy et al., 2020). Several mechanisms could be used by tomato seedlings under heat stress likealleviating the oxidative stress of non- and enzymatic antioxidants by applied spermidine, increase proline content, the activity of photosynthesis by applied salicylic acid, enhancing the thermo-tolerance of tomato seedlings to heat stress by applied ascorbic acid, controlling over-accumulation of hydrogen peroxide and superoxide and lowering the lipid peroxidation content through application of melatonin.

Therefore, it could be concluded that, the production of tomato seedlings under greenhouse conditions in arid and semi-arid zones in summer has a crucial problem represents in the heat stress. This production definitely requires more precautions and the effective management. This heat stress may cause over accumulations of ROS leading to mis-folds or dis-organized cellular homeostasis, deformed the structure of protein and impeded its synthesis as well asthe disruption ofthe cell division and its growth due tothe reduction in seedling water content (Jahan et al., 2019). The photosynthesis also will be damaged under heat stress through altering the photosynthetic components such as the thylakoid membranes, the photosystem II complex and the enzyme of ribulose 1,5-bisphosphate carboxylase (Sakhonwasee and Phingkasan, 2017).

Due to its potential for human nutrition, tomato cultivation under different environmental conditions is a crucial issue. So, the cultivation of tomato in open fields and under greenhouses is a common approach. The tomato cultivation under the greenhouse has become popular in different countries for the intensive production. This intensive production requires overapplication of chemical fertilizers, which may cause greenhouse gas emissions including $\mathrm{CH}_{4}$, $\mathrm{CO}_{2}$, and $\mathrm{N}_{2}$ Ocontribute to global warming (Maham et al., 2020). This problem could be distinguished particularly in arid and semi-arid zones, which the greenhouse in summer may create a heat stress leading to soil salinization and damage for cultivated plants. These elevated temperatures in greenhouse may cause heat stress leading to generate oxidative stress and ROS, which severely damage the yield of tomato (Tonhati et al., 2020).

It is worth to mention that, the optimum temperature for tomato seedlings growth ranges from 18 to $30{ }^{\circ} \mathrm{C}$, whereas the growing of seedling may decrease when it increases more than $35{ }^{\circ} \mathrm{C}$ (EL-Aidy et al. 2020). On the other hand, the optimum temperature during tomato plant flowering and fruit growth ranges from 18 to $25{ }^{\circ} \mathrm{C}$ (Tonhati et al., 2020). Therefore, the growth and production of tomato seedlings under greenhouse conditions may mainly depends on the growth stage, the stressful conditions and its duration, which control to what extent control the damage in cell metabolism functions. Again, the heat stress for tomato seedlings may include shortening the growth cycle, accelerating seedling senescence and leading to significant losses in tomato yield (Tonhati et al., 2020). 
TABLE 2. Response of tomato seedlings to heat stress and its growth conditions.

\begin{tabular}{|c|c|c|c|}
\hline $\begin{array}{l}\text { Seedling age at heat } \\
\text { stress treating }\end{array}$ & $\begin{array}{c}\text { Growth } \\
\text { conditions(cultivated } \\
\text { cultivar) }\end{array}$ & Most important findings of the study & Reference \\
\hline $\begin{array}{l}\text { At the } 3^{\text {rd }} \text { true leaf, } \\
38 / 28^{\circ} \mathrm{C} \text { day/night for } \\
7 \text { days, spaying } 1 \mathrm{mM} \\
\text { spermidine }\end{array}$ & $\begin{array}{l}\text { Growth chamber } \\
\text { (cv. Puhong 968) }\end{array}$ & $\begin{array}{l}\text { Spraying spermidine may alleviate the } \\
\text { damage of heat stress through enhancing } \\
\text { oxidative stress of non- and enzymatic } \\
\text { antioxidants }\end{array}$ & $\begin{array}{l}\text { Sang et al. } \\
\quad(2016)\end{array}$ \\
\hline $\begin{array}{l}\text { At the } 3^{\text {rd }} \text { week old of } \\
\text { seedlings, } 39 / 29^{\circ} \mathrm{C} \text { for } \\
14 \text { days }\end{array}$ & $\begin{array}{l}\text { Growth chamber } \\
\text { (cv. Luktho) }\end{array}$ & $\begin{array}{l}\text { Foliar application of the } \mathrm{CaCl}_{2}, \mathrm{CaNO}_{3} \text {, } \\
\mathrm{MgCl}_{2} \text {, or } \mathrm{KNO}_{3} \text { solution mitigated heat } \\
\text { stress effect by reducing the ROS }\end{array}$ & $\begin{array}{l}\text { Sakhonwasee } \\
\text { and Phingkasan } \\
\text { (2017) }\end{array}$ \\
\hline $\begin{array}{l}\text { After transfer into } \\
\text { hydroponics, } 40^{\circ} \mathrm{C} \text { for } 8 \\
\text { h/day for } 7 \text { days, applied } \\
0.5 \text { mM AsA }\end{array}$ & $\begin{array}{l}\text { Plants were grown in peat } \\
\text { moss for } 35 \text { days, then } \\
\text { transferred into hydroponic } \\
\text { system }\end{array}$ & $\begin{array}{l}\text { Ascorbic acid (AsA) may be considered } \\
\text { a key signaling molecule enhances the } \\
\text { thermo-tolerance of tomato seedlings }\end{array}$ & Alayafi (2019) \\
\hline $\begin{array}{l}\text { Seedlings transferred } \\
\text { into pots, grown for } 25 \\
\text { days at } 45 / 32^{\circ} \mathrm{C} \text { (day/ } \\
\text { night) }\end{array}$ & $\begin{array}{l}\text { Growth chamber, (NUN } \\
5024 \text { var.), seeds primed in } \\
\operatorname{Mg}\left(\mathrm{NO}_{3}\right)_{2}\end{array}$ & $\begin{array}{l}\text { Priming seeds in } \mathrm{Mg}\left(\mathrm{NO}_{3}\right)_{2} \text { (from } 5 \text { to } 10 \\
\mathrm{mM}) \text { may improve germination in normal } \\
\left(25^{\circ} \mathrm{C}\right) \text { and ameliorate high temperature } \\
\text { stress }\left(40^{\circ} \mathrm{C}\right)\end{array}$ & $\begin{array}{l}\text { Nafees et al. } \\
\text { (2019) }\end{array}$ \\
\hline $\begin{array}{l}\text { At the } 5^{\text {th }} \text { true leaf, } \\
\text { seedlings exposed to } 42 \\
{ }^{\circ} \mathrm{C} \text { for } 36 \mathrm{~h}\end{array}$ & $\begin{array}{l}\text { Growth chamber (cv. } \\
\text { Hezuo 903), at } 28 / 19^{\circ} \mathrm{C} \\
\text { (day/night), salicylic acid } \\
(1 \mathrm{mM}) \text { sprayed for } 7 \text { days }\end{array}$ & $\begin{array}{l}\text { Salicylic acid may increase proline } \\
\text { content, the activity of photosynthesis } \\
\text { and antioxidant enzyme functions }\end{array}$ & $\begin{array}{l}\text { Jahan et al. } \\
\text { (2019) }\end{array}$ \\
\hline $\begin{array}{l}\text { At the } 4^{\text {th }} \text { true leaf, } \\
\text { seedlings exposed to } 42 \\
{ }^{\circ} \mathrm{C} \text { for } 24 \mathrm{~h}\end{array}$ & $\begin{array}{l}\text { Growth chamber (cv. } \\
\text { Hezuo } 903) \text {, at } 28 / 19^{\circ} \mathrm{C} \\
\text { (day/night), melatonin }(100 \\
\mu \mathrm{M}) \text { sprayed for } 7 \text { days }\end{array}$ & $\begin{array}{l}\text { Melatonin may control over- } \\
\text { accumulation of hydrogen peroxide } \\
\text { and superoxide, then lowering the lipid } \\
\text { peroxidation content }\end{array}$ & $\begin{array}{l}\text { Jahan et al. } \\
(2020 \mathrm{~b})\end{array}$ \\
\hline $\begin{array}{l}\text { At } 18^{\text {th }} \text { day-old } \\
\text { seedlings, sprayed } 3 \\
\text { times and sampling after } \\
4 \text { and } 5 \text { weeks }\end{array}$ & $\begin{array}{l}\text { In greenhouse (super strain } \\
\mathrm{B} \text { variety), under heat stress } \\
45 / 27^{\circ} \mathrm{C} \text { (day/night) for } 35 \\
\text { days }\end{array}$ & $\begin{array}{l}\text { Foliar application of sucrose }(10 \%) \\
\text { silicon }\left(500 \mathrm{mgl}^{-1}\right) \text { and plant probiotics } \\
\left(100 \mathrm{mgl}^{-1}\right) \text { improved growth and quality } \\
\text { of tomato seedlings }\end{array}$ & $\begin{array}{l}\text { EL-Aidy et al. } \\
\qquad(2020)\end{array}$ \\
\hline
\end{tabular}

Cultivated plants like other organisms are facing different abiotic and biotic stresses during their life and should adapt towards this stress. This adaptation is including the defense of these plants for their existence. This defense system has the ability to manage the plant genes in the regulation of all plant processes of growth and development. This regulation is considered stress management (Barozai and Aziz, 2018). The heatstress management could be achieved viaplant conventional breeding and plant engineering using the genetic approaches (Ye et al., 2019), as well as many agronomic practices (Fahad et al., 2017). These practices include exogenous application of osmo-protectants and growth regulators (Fahad et al. 2017), calcium compounds, spermidine, ascorbic acid, nitrate compounds, salicylic acid, melatonin, sucrose and silicon (as presented in Table 2) as well as nanoparticles (Ye et al., 2019). 


\section{Conclusion}

The universe suffers from climate changes and global warming, which lead to increase the atmospheric temperature especially under the greenhouse conditions. Under arid conditions, the production of tomato seedlings under greenhouse system during the highest temperatures (mainly July and August) is a great challenge due to the heat stress inside and outside the greenhouse. So, this production should be managed through application the proper amendments including the chemical (e.g., Si, Se, Ca, Mg), organic (e.g., sucrose, spermidine, ascorbic acid, melatonin and proline) and biological candidates (e.g., plant probiotics). The heat stress may cause a serious threat for tomato seedlings production under such previous conditions, which generates a huge amount of ROS and oxidative stress. This stress also may reduce the photosynthetic activity in seedlings, the water content, metabolic processes and decline the growth rates and in turn the projected yield of tomato. Therefore, further studies are needed on the physiological, biochemical, anatomical and molecular levels in tomato seedlings under heat stress. The agronomic approaches and nanomaterials also are needed for more studies as management tools for heat stress.

\section{Acknowledgement}

The authors thank the staff members of Physiology and Breeding of Horticultural Crops Laboratory, Dept. of Horticulture, Fac. of Agric., Kafrelsheikh University, Kafr El-Sheikh, Egypt for supporting this work.

\section{References}

Agathokleous, E., Kitao, M. and E. J. Calabrese (2019) New insights into the role of melatonin in plants and animals. Chemico-Biological Interactions. doi:10.1016/j.cbi.2018.12.008

Ahanger, M. A., Mir, R. A., Alyemeni, M. N. and P. Ahmad (2020) Combined effects of brassinosteroid and kinetin mitigates salinity stress in tomato through the modulation of antioxidant and osmolyte metabolism. Plant Physiology and Biochemistry. doi:10.1016/j.plaphy.2019.12.007

Ahmad, P., Ahanger, M. A., Alyemeni, M. N., Wijaya, L. and P. Alam (2018) Exogenous application of nitric oxide modulates osmolyte metabolism, antioxidants, enzymes of ascorbate-glutathione cycle and promotes growth under cadmium stress in tomato. Protoplasma, 255 (1), 79-93. doi:10.1007/ s00709-017-1132-x

Alayafi, A. A. M. (2019) Exogenous ascorbic acid induces systemic heat stress tolerance in tomato seedlings: transcriptional regulation mechanism. Environmental Science and Pollution Research, https://doi.org/10.1007/s11356-019-06195-7

Alsuhaibani, A. M. A. (2018) Chemical Composition and Ameliorative Effect of Tomato on Isoproterenol-induced Myocardial Infarction in Rats. Asian J. Clin.Nutr. 10 (1): 1-7. DOI: 10.3923/ ajcn.2018.1.7

Alyemeni, M. N., Ahanger, M. A., Wijaya, L., Alam, P.,Bhardwaj, R. and P. Ahmad (2018) Selenium mitigates cadmium-induced oxidative stress in tomato (Solanum lycopersicum L.) plants by modulating chlorophyll fluorescence, osmolyte accumulation, and antioxidant system. Protoplasma, 255 (2), 459-469. doi:10.1007/ s00709-017-1162-4

Amer, M., Aiad, M., Rashed, S. and H. El-Ramady (2019) Sustainable Irrigation and Fertilization Management of Successive Cultivated Sugar Beet and Cotton under Salt-affected Soil Conditions. Env.Biodiv. Soil Security, 3, 227 - 239. DOI: 10.21608/jenvbs.2019.20394.1076

Arnao, M. B. and J. Hernández-Ruiz (2019) Melatonin: A New Plant Hormone and/or a Plant Master Regulator? Trends in Plant Science. doi:10.1016/j. tplants.2018.10.010

Barozai, M. Y. K. and A.N. Aziz (2018)Recent plant growth and stress management related significant advancements in epigenetics. Annals of Agrarian Science, 16 (4): 416-421. doi:10.1016/j. aasci.2018.07.002

Bian, Z., Zhang X., Wang Y. andC. Lu C (2019) Improving drought tolerance by altering the photosynthetic rate and stomatal aperture via green light in tomato (Solanumlycopersicum L.) seedlings under drought conditions. Environmental and Experimental Botany, 103844. doi:10.1016/j. envexpbot.2019.103844

Bilal, S., Shahzad, R., Imran, M., Jan, R., Kim, K. M., and I.J. Lee (2020) Synergistic association of endophytic fungi enhances Glycine max L. resilience to combined abiotic stresses: Heavy metals, high temperature and drought stress. Industrial Crops and Products, 143, 111931. https://doi.org/10.1016/j.indcrop.2019.111931

Bouain, N., Krouk, G., Lacombe, B., and H. Rouached 
(2019) Getting to the Root of Plant Mineral Nutrition: Combinatorial Nutrient Stresses Reveal Emergent Properties. Trends in Plant Science, doi:10.1016/j.tplants.2019.03.008

Dai,L., Li, J., Harmens, H., Zheng, X. and Zhang, C. (2020). Melatonin enhances drought resistance by regulating leaf stomatal behaviour root growth and catalase activity in two contrasting rapeseed (Brassica napus L.) genotypes. Plant Physiology and Biochemistry, 149, 86-95. https://doi. org/10.1016/j.plaphy.2020.01.039

Dong, Y., Wang, X. and X. Cui (2013) Exogenous Nitric Oxide Involved in Subcellular Distribution and Chemical Forms of $\mathrm{Cu}^{2+}$ Under Copper Stress in Tomato Seedlings. J. Integrative Agriculture, 12 (10): 1783-1790. doi: 10.1016/S20953119(13)60367-6

Dong, Z., Men, Y., Liu, Z., Li, J., and J. Ji (2020) Application of chlorophyll fluorescence imaging technique in analysis and detection of chilling injury of tomato seedlings. Computers and Electronics in Agriculture, 105109. doi:10.1016/j. compag.2019.105109

EL-Aidy, F., Abdullah, M., EL-Sawy, M., El Kady, S. A., Bayoumi, Y. and H. El-Ramady (2020) Production of Tomato Seedlings under High Temperature Stress in Greenhouse: The Role of Plant Probiotics, Sucrose and Silicon. Fresen Environ Bull. (submitted)

Elkelish, A. A., Alhaithloul, H. A. S., Qari, S. H., Soliman, M. H. and M. Hasanuzzaman (2020) Pretreatment with Trichodermaharzianum alleviates waterlogging-induced growth alterations in tomato seedlings by modulating physiological, biochemical, and molecular mechanisms. Environmental and Experimental Botany, 103946. doi:10.1016/j.envexpbot.2019.103946

El-Ramady, H., Olle, M., Eichler-Löbermann, B. and E. Schnug (2020) Towards A New Concept of Sustainable Plant Nutrition.Env. Biodiv. Soil Security, 4, 1 - 7. DOI: 10.21608/ jenvbs.2020.21970.1080

Elsakhawy, T., Omara, A., Alshaal, T. and H. El-Ramady (2018) Nanomaterials and Plant Abiotic Stress in Agroecosystems. Env.Biodiv. Soil Security, 2, 73 94. DOI: 10.21608/JENVBS.2018.3897.1030

Fahad, S., Bajwa, A.A., Nazir, U., Anjum, S.A., Farooq, A., Zohaib, A., Sadia, S., Nasim, W., Adkins, S., Saud, S. and M.Z. Ihsan (2017) Crop production under drought and heat stress: plant responses and management options. Frontiers in Plant Science, 8, p.1147.doi:10.3389/fpls.2017.01147

FAOSTAT (2020). Crops: tomatoes. http://www.fao. org/faostat/en/\#data/QC, extracted on 9 August, 2019

Ghani, S., Bakochristou, F., ElBialy, E. M. A. A., Gamaledin, S. M. A., Rashwan, M. M., Ayman, M. A. and M. I. Salman(2019) Design challenges of agriculture greenhouses in hot and arid environment - A review. Engineering in Agriculture, Environment and Food, 12 (1), 48-70. doi:10.1016/j.eaef.2018.09.004

González-Hernández, A. I., Scalschi, L., GarcíaAgustín, P. and G. Camañes 2020) Tomato root development and $\mathrm{N}$ assimilation depend on $\mathrm{C}$ and ABA content under different $\mathrm{N}$ sources. Plant Physiology and Biochemistry, doi:10.1016/j. plaphy.2020.01.031

Gupta, D. K., Palma, J. M. and F. J. Corpas (2019) Nitric Oxide and Hydrogen Peroxide Signaling in Higher Plants. https://doi.org/10.1007/978-3-03011129-8, Springer Nature Switzerland AG

Hu, M., Dou, Q., Cui, X., Lou, Y. and Y.Zhunge (2019) Polyaspartic acid mediates the absorption and translocation of mineral elements in tomato seedlings under combined copper and cadmium stress. J. Integrative Agriculture, 18 (5), 11301137. doi:10.1016/s2095-3119(18)62017-9

Jahan, M. S., Guo S., Baloch A., Sun J. and R. Roy (2020b) Melatonin alleviates nickel phytotoxicity by improving photosynthesis, secondary metabolism and oxidative stress tolerance in tomato seedlings. Ecotoxicology and Environmental Safety, https:// doi.org/10.1016/j.ecoenv.2020.110593

Jahan M. S., Shu S., Wang Y., Chen Z., He M., Tao M., Sun J. and S.Guo (2020a) Melatonin alleviates heatinduced damage of tomato seedlings by balancing redox homeostasis and modulating polyamine and nitric oxide biosynthesis. BMC Plant Biology, 19:414 https://doi.org/10.1186/s12870-019-1992-7

Jahan, M. S., Wang, Y., Shu, S., Zhong, M., Chen, Z., Wu, J., Sun, J. and S.Guo (2019) Exogenous salicylic acid increases the heat tolerance in Tomato (Solanum lycopersicum L) by enhancing photosynthesis efficiency and improving antioxidant defense system through scavenging of reactive oxygen species. ScientiaHorticulturae, 247, 421-429. doi:10.1016/j.scienta.2018.12.047

Jangid, K. K. and P. Dwivedi (2017) Physiological 
and biochemical changes by nitric oxide and brassinosteroid in tomato (Lycopersiconesculentum Mill.) under drought stress. Acta Physiologiae Plantarum, 39(3). doi:10.1007/s11738-017-2373-1

Kaya, C. and M. Ashraf (2015) Exogenous application of nitric oxide promotes growth and oxidative defense system in highly boron stressed tomato plants bearing fruit. ScientiaHorticulturae, 185: 4347. https://doi.org/10.1016/j.scienta.2015.01.009

Kaya, C., Ashraf, M., Alyemeni, M. N. and P. Ahmad(2020)The role of nitrate reductase in brassinosteroid-induced endogenous nitric oxide generation to improve cadmium stress tolerance of pepper plants by upregulating the ascorbate-glutathione cycle. Ecotoxicology and Environmental Safety, 196, 110483. doi:10.1016/j. ecoenv.2020.110483

Khan, T. A., Yusuf, M., Ahmad, A., Bashir, Z., Saeed, T., Fariduddin, Q., Hayatf S., Mock H.-P. andT. $\mathrm{Wu}$ (2019) Proteomic and physiological assessment of stress sensitive and tolerant variety of tomato treated with brassinosteroids and hydrogen peroxide under low-temperature stress. Food Chemistry, doi:10.1016/j.foodchem.2019.03.029

Lee, J., Shim, D., Moon, S., Kim, H., Bae, W., Kim, K., Kim, Y-H., Rhee, S-K., Hong, C. P., Hong, S-Y., Lee, Y-J, Sung, J. andH.Ryu(2018) Genome-wide transcriptomic analysis of BR-deficient MicroTom reveals correlations between drought stress tolerance and brassinosteroid signaling in tomato. Plant Physiology and Biochemistry, 127, 553-560. doi:10.1016/j.plaphy.2018.04.031

Liang, Y., Lin, X., Yamada, S., Inoue, M. and K.Inosako(2013) Soil degradation and prevention in greenhouse production. SpringerPlus, 2 (Suppl 1), S10.doi:10.1186/2193-1801-2-s1-s10

Liu, X., Zhang, Q., Yang, G., Zhang, C., Dong, H., Liu, Y., Yin, R. and L. Lin(2020) Pivotal roles of Tomato photoreceptor SIUVR8 in seedling development and UV-B stress tolerance. Biochemical and Biophysical Research Communications. doi:10.1016/j.bbrc.2019.11.073

Lyu, J. I., Park, J. H., Kim, J.-K., Bae, C.-H., Jeong, W.-J., Min, S. R. and J. R. Liu (2018) Enhanced tolerance to heat stress in transgenic tomato seeds and seedlings overexpressing a trehalose-6phosphate synthase/phosphatase fusion gene. Plant Biotechnology Reports. doi:10.1007/s11816-0180505-8

Maham, S. G., Rahimi, A., Subramanian, S. and D.
L. Smith(2020)The environmental impacts of organic greenhouse tomato production based on the nitrogen-fixing plant (Azolla). Journal of Cleaner Production, 118679. doi:10.1016/j. jclepro.2019.118679

Mukherjee, S. (2018) Novel perspectives on the molecular crosstalk mechanisms of serotonin and melatonin in plants. Plant Physiology and Biochemistry, doi:10.1016/j.plaphy.2018.08.031

Nafees, K., Kumar, M. and B. Bose(2019) Effect of Different Temperatures on Germination and Seedling Growth of Primed Seeds of Tomato. Russian J. Plant Physiology, 66 (5), 778-784. doi:10.1134/s1021443719050169

Naz, R., Khan, I., Gul, B., Ayub, G., Jan, F., Jang, N. and M.Shuaib(2019) Response of tomato (Lycopersiconesculentum Mill.) growth to different phosphorous levels and sowing dates. ActaEcologicaSinica, 39, 30-35. https://doi. org/10.1016/j.chnaes.2018.06.004

Nie, S., Huang, S., Wang, S., Mao, Y., Liu, J., Ma, R. and X. Wang(2019) Enhanced brassinosteroid signaling intensity via SIBRI1 overexpression negatively regulates drought resistance in a manner opposite of that via exogenous BR application in tomato. Plant Physiology and Biochemistry. doi:10.1016/j.plaphy.2019.02.014

Nordey, T., Basset-Mens, C., De Bon, H., Martin, T., Déletré, E., Simon, S., Parrot L., Despretz H., Huat J., Biard Y., Dubois T. and E. Malézieux(2017) Protected cultivation of vegetable crops in sub-Saharan Africa: limits and prospects for smallholders. A review. Agronomy for Sustainable Development, 37(6). doi:10.1007/s13593-0170460-8

Pandey, A., Devi, L. L. andA. P. Singh(2020) Review: Emerging roles of brassinosteroid in nutrient foraging. Plant Science, 110474. doi:10.1016/j. plantsci.2020.110474

Reddy, P. P. (2016) Protected Cultivation. In: P.P. Reddy (author), Sustainable Crop Protection under Protected Cultivation. Springer Science + Business Media Singapore, DOI 10.1007/978-981-287-9523_1, pp: $1-11$.

Sadura, I., Libik-Konieczny, M., Jurczyk, B., Gruszka, D. and A.Janeczko (2020) Plasma membrane ATPase and the aquaporin HvPIP1 in barley brassinosteroid mutants acclimated to high and low temperature. J. Plant Physiology, 153090. doi:10.1016/j.jplph.2019.153090 
Sakhonwasee, S. and W.Phingkasan(2017) Effects of the foliar application of calcium on photosynthesis, reactive oxygen species production, and changes in water relations in tomato seedlings under heat stress. Horticulture, Environment, and Biotechnology, 58 (2), 119-126. doi:10.1007/s13580-017-0194-1

Saldaña-Sánchez, W. D., León-Morales, J. M., LópezBibiano, Y., Hernández-Hernández, M., LangaricaVelázquez, E. C. and S.García-Morales (2019) Effect of V, Se, and Ce on Growth, Photosynthetic Pigments, and Total Phenol Content of Tomato and Pepper Seedlings. J. Soil Science and Plant Nutrition, doi:10.1007/s42729-019-00068-1

Sang, Q. Q., Shu, S., Shan, X., Guo, S. R. and J. Sun(2016) Effects of exogenous spermidine on antioxidant system of tomato seedlings exposed to high temperature stress. Russian Journal of Plant Physiology, 63 (5), 645-655. doi:10.1134/ s1021443716050113

Seleiman, M. F., Ali, S., Refay, Y., Rizwan, M., Alhammad, B. A. and S. E. El-Hendawy(2020) Chromium resistant microbes and melatonin reduced $\mathrm{Cr}$ uptake and toxicity, improved physio-biochemical traits and yield of wheat in contaminated soil. Chemosphere, $250 \mathrm{https}$ ://doi. org/10.1016/j.chemosphere.2020.126239

Setsungnern, A., Muñoz, P., Pérez-Llorca, M., Müller, M., Thiravetyan, P. and S.Munné-Bosch (2020).A Defect in BRI1-EMS-SUPPRESSOR 1 (BES1)-Mediated Brassinosteroid Signaling Increases Photoinhibition and Photo-oxidative Stress during Heat Stress Acclimation in Arabidopsis. Plant Science, 110470. doi:10.1016/j. plantsci.2020.110470

Shurpali, N., Agarwal, A. K. and V. K. Srivastava(2019) Greenhouse Gas Emissions Challenges, Technologies and Solutions.Energy, Environment, and Sustainability Book Series, https://doi. org/10.1007/978-981-13-3272-2, Springer Nature Singapore Pte Ltd.

Siddiqui, M. H., Alamri, S. A., Al-Khaishany, M. Y., Al-Qutami, M. A., Ali, H. M., AL-Rabiah, H. and H. M. Kalaji (2017) Exogenous application of nitric oxide and spermidine reduces the negative effects of salt stress on tomato. Horticulture, Environment, and Biotechnology, 58 (6), 537-547. doi:10.1007/ s13580-017-0353-4

Siddiqui, M. H., Alamri, S., Alsubaie, Q. D., Ali, H. M., Ibrahim, A. A. and A.Alsadon (2019) Potential roles of melatonin and sulfur in alleviation of lanthanum toxicity in tomato seedlings. Ecotoxicology and Environmental Safety, 180, 656-667. doi:10.1016/j. ecoenv.2019.05.043

Siddiqui, M. H., Alamri, S., Alsubaie, Q. D., Ali, H. M., Khan, M. N., Al-Ghamdi, A., Ibrahim, A. A. and A.Alsadon(2020) Exogenous nitric oxide alleviates sulfur deficiency-induced oxidative damage in tomato seedlings. Nitric Oxide, 94: 95107. doi:10.1016/j.niox.2019.11.002

Singh, S., Singh, A., Srivastava, P. K. and S. M. Prasad(2018) Cadmium toxicity and its amelioration by kinetin in tomato seedlings visà-vis ascorbate-glutathione cycle. Journal of Photochemistry and Photobiology B: Biology, 178, 76-84. doi:10.1016/j.jphotobiol.2017.10.025

Singh, V. K., Singh, A. K., Singh, P. P. and A. Kumar (2018) Interaction of plant growth promoting bacteria with tomato under abiotic stress: A review. Agriculture, Ecosystems and Environment, 267, 129-140. doi:10.1016/j.agee.2018.08.020

Soares, T.F.S.N., dos Santos Dias, D.C.F., Oliveira, A.M.S., Ribeiro, D.M. and L.A. dos Santos Dias(2020) Exogenous brassinosteroids increase lead stress tolerance in seed germination and seedling growth of Brassica juncea L. Ecotoxicology and Environmental Safety, 193, p.110296.doi:10.1016/j.ecoenv.2020.110296

Souza, A. C. and J. A. Prevedello(2020) The importance of protected areas for overexploited plants: Evidence from a biodiversity hotspot. Biological Conservation, 243, 108482. doi:10.1016/j. biocon.2020.108482

Sun, J., Pan, L., Li, Z., Zeng, Q., Wang, L. and L. Zhu(2018) Comparison of greenhouse and open field cultivations across China: Soil characteristics, contamination and microbial diversity. Environmental Pollution, doi:10.1016/j. envpol.2018.09.112

Tong, H. and C. Chu(2018) Functional Specificities of Brassinosteroid and Potential Utilization for Crop Improvement. Trends in Plant Science. doi:10.1016/j.tplants.2018.08.007

Tonhati, R., Mello, S. C., Momesso, P. and R. M. Pedroso(2020) L-proline alleviates heat stress of tomato plants grown under protected environment. ScientiaHorticulturae, 268, 109370. doi:10.1016/j. scienta.2020.109370

Wan, J. (2015) Engineering thermotolerant plants: a solution to protecting crop production threatened 
by global warming. Science Bulletin, 60 (15), 1366-1367. doi:10.1007/s11434-015-0843-7

Wang J., Yu S. X., Zhang, M. and X. M. Cui (2015) Exogenous Nitric Oxide Mediated GSH-PC Synthesis Pathway in Tomato under Copper Stress. 7, Russian Journal of Plant Physiology, 62 (3), 349-359. DOI: 10.1134/S1021443715030188

Wang, M., Peng, Q., Zhou, F., Yang, W., Dinh, Q. T. and D. Liang(2019) Uptake kinetics and interaction of selenium species in tomato (Solanum lycopersicum L.) seedlings. Environmental Science and Pollution Research. doi:10.1007/s11356-019-04182-6

Wei, L., Zhang, J., Wang, C. and W. Liao(2020) Recent progress in the knowledge on the alleviating effect of nitric oxide on heavy metal stress in plants. Plant Physiology and Biochemistry, 147, 161-171. doi:10.1016/j.plaphy.2019.12.021

Ye, Y., Medina-Velo, I. A., Cota-Ruiz, K., MorenoOlivas, F. and J. L.Gardea-Torresdey (2019) Can abiotic stresses in plants be alleviated by manganese nanoparticles or compounds? Ecotoxicology and Environmental Safety, 184, 109671. doi:10.1016/j. ecoenv.2019.109671

Zahedi, S. M., Hosseini, M. S., Abadía, J. and M.Marjani(2020) Melatonin foliar sprays elicit salinity stress tolerance and enhance fruit yield and quality in strawberry (Fragaria $\times$ ananassaDuch.). Plant Physiology and Biochemistry, 149: 313-323. https://doi.org/10.1016/j.plaphy.2020.02.021

Andalinas, S.I., Mittler, R., Balfagón, D., Arbona, V. and A. Gómez-Cadenas (2018) Plant adaptations to the combination of drought and high temperatures. Physiol Plant, 162, 2-12. DOI: $10.1111 /$ ppl.12540

Zhang, Y., Shi, Y., Gong, H-J., Zhao, H-L.andY-C. Wang (2018) Beneficial effects of silicon on photosynthesis of tomato seedlings under water stress. Journal of Integrative Agriculture, 17 (10): 2151-2159. doi: 10.1016/S2095-3119(18)62038-6

Zhang, Y., Zhou, Y., Chen, S., Liu, J., Fan, K., Li, Z., Liu, Z. and W. Lin(2019) Gibberellins play dual roles in response to phosphate starvation of tomato seedlings, negatively in shoots but positively in roots. J. Plant Physiology. doi:10.1016/j. jplph.2019.02.007

Zhang, Z., Cao, B., Li, N., Chen, Z. and K. Xu (2019) Comparative transcriptome analysis of the regulation of $\mathrm{ABA}$ signaling genes in different rootstock grafted tomato seedlings under drought stress. Environmental and Experimental Botany, 166, 103814. doi:10.1016/j.envexpbot.2019.103814

Zhao, X., Han, L., Xiao, J., Wang, L., Liang, T. and X. Liao(2020) A comparative study of the physiological and biochemical properties of tomato (Lycopersiconesculentum M.) and maize (Zea mays L.) under palladium stress. Science of the Total Environment, 135938. doi:10.1016/j. scitotenv.2019.135938

Zhou, R., Yu, X., Li, X., Mendanha dos Santos, T., Rosenqvist, E. and C.-O. Ottosen (2020) Combined high light and heat stress induced complex response in tomato with better leaf cooling after heat priming. Plant Physiology and Biochemistry, 151, 1-9. doi:10.1016/j.plaphy.2020.03.011

Zhou, R., Yu, X., Ottosen, C.-O., Rosenqvist, E., Zhao, L., Wang, Y.,Wang Y.,, Yu W., Zhao T. and Z. Wu (2017) Drought stress had a predominant effect over heat stress on three tomato cultivars subjected to combined stress. BMC Plant Biology, 17 (1). doi:10.1186/s12870-017-0974-x

Zhou, Y., Diao, M., Chen, X., Cui, J., Pang, S., Li, Y., Hou, C. and H. Liu (2019) Application of exogenous glutathione confers salinity stress tolerance in tomato seedlings by modulating ions homeostasis and polyamine metabolism. ScientiaHorticulturae, 250, 45-58. doi:10.1016/j.scienta.2019.02.026 